2002-01-01

\title{
Performance of fisheries sector planning in Bangladesh
}

\author{
Rahman, Sanzidur
}

http://hdl.handle.net/10026.1/4034

10.5367/000000002101294137

Outlook on Agriculture

SAGE Publications

All content in PEARL is protected by copyright law. Author manuscripts are made available in accordance with publisher policies. Please cite only the published version using the details provided on the item record or document. In the absence of an open licence (e.g. Creative Commons), permissions for further reuse of content should be sought from the publisher or author. 


\title{
Performance of fisheries sector planning in Bangladesh
}

\author{
Sanzidur Rahman and K.K. Ahmed
}

Abstract: The overall planning performance of the fisheries sector in Bangladesh over the past three decades was evaluated. Performance has been unsatisfactory largely due to contiguous overestimation of the planning targets and the existence of serious financial, technological, institutional and social constraints. Despite the remarkable growth in export earnings and a stable GDP contribution of 3.2-5.6\%, budget allocations remained extremely low (0.7-1.4\% of total outlay) in subsequent plan periods. Production from marine fisheries performed satisfactorily with slow growth in recent years, while inland fisheries with initial poor performance showed improvements from the mid-1980s owing to increased productivity in culture fisheries, particularly in pond aquaculture. Targets should be determined with the aid of a thorough review of past performances and there is an urgent need to streamline the implementation capability. Also, a shift from productionoriented planning and seeking technical solutions only to addressing broader institutional and social issues affecting the fisheries sector is essential. Government should emphasize the development of small-scale fisheries, strengthen extension-research linkage, improve infrastructure, build partnerships between relevant agencies and shift its top-down approach to planning towards a participatory bottom-up approach so as to release existing bottlenecks.

Keywords: fisheries planning; fish production growth; Bangladesh

Sanzidur Rahman is a Hallsworth Research Fellow with the School of Economic Studies, University of Manchester, Oxford Road, Manchester M13 9PL, UK. Tel: +44 161275 4865. Fax: +44 161275 4812. E-mail: Sanzidur.Rahman@man.ac.uk. K.K. Ahmed is Senior Scientific Officer at the Riverine Sub-station, Bangladesh Fisheries Research Institute, Rangamati, Bangladesh.

Fisheries play a significant role in meeting nutritional requirements, generating employment and earning foreign exchange for Bangladesh. Fish alone supplies about $60 \%$ of the requirement for animal protein. The sector directly employs about 1.2 million people, and an estimated 11 million people earn their livelihood from activities indirectly related to fisheries (Planning Commission PC, 1998).

Bangladesh enjoys one of the highest man-water ratios in the world, estimated at 20 persons per ha of water body (Task Force Report - TFR, 1991) and is very rich in inland water suited to fish production, by virtue of being a delta of the major river systems in the region, ie the Ganges, Brahmaputra and Meghna. A total of 230 large and small rivers traverses the country (Bangladesh Bureau of
Statistics - BBS, 1998). About 5.5 million ha of floodplain remain inundated at various depths during the monsoon season (Master Plan Organization - MPO, 1989). There are approximately $4.41 \mathrm{~m}$ ha of inland open water bodies comprising $1.03 \mathrm{~m}$ ha of rivers and estuaries, $2.83 \mathrm{~m}$ ha of floodlands, $0.11 \mathrm{~m}$ ha of beels (year-round depressions) and $0.07 \mathrm{~m}$ ha of Kaptai lake (the largest man-made reservoir); and $0.36 \mathrm{~m}$ ha of closed water bodies comprising $0.21 \mathrm{~m}$ ha of ponds and dighis (big ponds), $0.01 \mathrm{~m}$ ha of baors (ox-bow lakes) and $0.14 \mathrm{~m}$ ha of coastal shrimp farms (BBS, 2001a). Also, the marine waters extend to an estimated $16.61 \mathrm{~m}$ ha of sea area under the 200 nautical miles of Exclusive Economic Zone (EEZ) criteria (Department of Fisheries DoF, 1998).

With the exception of privately owned ponds (and a 
few beels), all fisheries resources in Bangladesh are owned and managed by the public sector, which is solely responsible for the planning, financing and implementation of fisheries development programmes. The Ministry of Fisheries and Livestock (MoFL) has overall responsibility for the development of the sector. The Department of Fisheries (DoF) is the key fisheries institution responsible for management, development, extension, training, conservation, quality control, law enforcement, policy advice and information collection (Lewis, 1997). The Bangladesh Fisheries Research Institute (BFRI), established in 1986, is responsible for conducting research on freshwater and marine fisheries.

Planning frameworks in Bangladesh usually adopt a centrally controlled top-down approach that follows the steps laid down in successive five-year plan documents. So far, five five-year plans and a two-year plan, plus a two-year plan holiday have been implemented. However, it was only in 1995 that a 15-Year Participatory

Perspective Plan (1995-2010) ${ }^{1}$ was prepared that clearly identified people as the centrepiece of development and emphasized growth and investment by building up institutional infrastructure for implementing programmes at the local level (PC, 1995a).

Despite the reported major thrust in developing the fisheries in all the successive plans, various impediments still exist towards meeting the desired goal. This paper critically analyses the overall planning performance of the fisheries sector in terms of allocation and utilization of funds as well as achieving the targets set forth in successive plans. The paper also examines the rationality of setting these physical targets, and the reasons for failing to achieve them over the past 26-year period (1973-1998). It also highlights the current constraints facing the fisheries sector. Finally, it offers some policy recommendations for enabling and sustaining the fisheries sector to meet its tripartite role of supplying protein, generating employment and earning foreign exchange for the economy.

\section{Outlook and performance of the fisheries sector}

\section{Contribution to national income}

The contribution of the fisheries sector to total gross domestic product (GDP) remained stable within a range of $3.2-5.6 \%$ between 1973 and 2000, while the share of total agriculture declined consistently from $50.9 \%$ to $29.7 \%$. Trend analysis reveals that although the contribution of the fisheries sector to total GDP dipped during the mid-70s, it recovered gradually and crossed the agricultural GDP index by the early 90 s and started to rise sharply, indicating its strong potential to contribute to national income if managed properly (Figure 1).

\section{Fund allocation and utilization}

In spite of the emphasis placed on the three key national objectives of increasing fish production, employment generation and foreign exchange earnings, fisheries were always underfunded and never reached even $1.5 \%$ of total government financial outlays in any of the plans (Table 1).
Moreover, in the fifth plan, currently under implementation, the outlay is the lowest of all in recent times (only $0.7 \%$ of the total), indicating the contrast between setting priorities and actual funding. Within the agricultural sector, the allocation remained at less than $5.5 \%$ in all the plans. In fact, the proportional allocations for fisheries always remained at less than half of their contribution to national income. The Annual

Development Programs (ADP) and/or Revised Annual Development Programs (RADP) further cut the already underfunded plan allocations: see, for instance, the actual allocation during the third plan. Coupled with poor allocation, the utilization performance of these allocations is also poor. Utilization remained at less than $50 \%$ in most cases, except for the Two-Year Plan and the second plan, which utilized $88 \%$ and $91 \%$ of plan allocations respectively, implying the existence of bottlenecks in governing agencies affecting performance (Table 1).

\section{Targets and achievements in fish production}

Failure to achieve the overestimated fish production targets was a routine phenomenon until 1990. In the first plan (1973-78), the target for fish production was set at 1.04 million tonnes ( $t$ ) for its terminal year of 1978 (PC, 1973). Actual fish production reached $0.64 \mathrm{~m} \mathrm{t}$, ie only $61.5 \%$ of the target was achieved (PC, 1978). The Two-Year Plan (1978-80) lowered the target to $0.82 \mathrm{~m} \mathrm{t}$. But actual production remained stagnant at $0.64 \mathrm{~m} \mathrm{t}$, with a $22 \%$ shortfall from the revised target (PC, 1985). The shortfall in both plans was mainly attributed to institutional bottlenecks, lack of extension and research linkages, multiplicity of control over the management of water bodies by various government agencies, poor design and development of projects and the inadequacy of trained personnel (Bhuiyan and Rahman, 1991). It was only from the time of the second plan that the achievement level started to improve gradually from $76 \%$ of the target to $97 \%$ in the fourth plan (Table 2). Despite shortfalls in overall fish production targets, achievements in the marine fisheries subsector consistently surpassed the target levels in all the plans, indicating its potential to boost production with proper planning and management.

\section{Trends in production, export and yield levels of fish}

Trends in fish production, export earnings and yield levels are presented in Figures 2, 3 and 4 respectively, with their growth rates in Table 3 . Although fish production from inland waters dipped towards the end of the first plan, it recovered slowly and then started to rise sharply from the second plan onwards (Figure 2). Marine fish production, on the other hand, showed a continued rise throughout, but at a very slow pace. Fluctuations in inland fish production affected the estimate of the overall growth rate in fish production for the period under study, as it constituted roughly three-quarters of total output (Table 3). However, estimates for recent years (1991-98) demonstrate the remarkable growth rate, thereby indicating its economic potential.

Although the share of total export earning attributed to fish and fisheries production started to fall sharply in the early 1990s, the value of export earnings increased consistently throughout (Figure 3) and the growth rate 


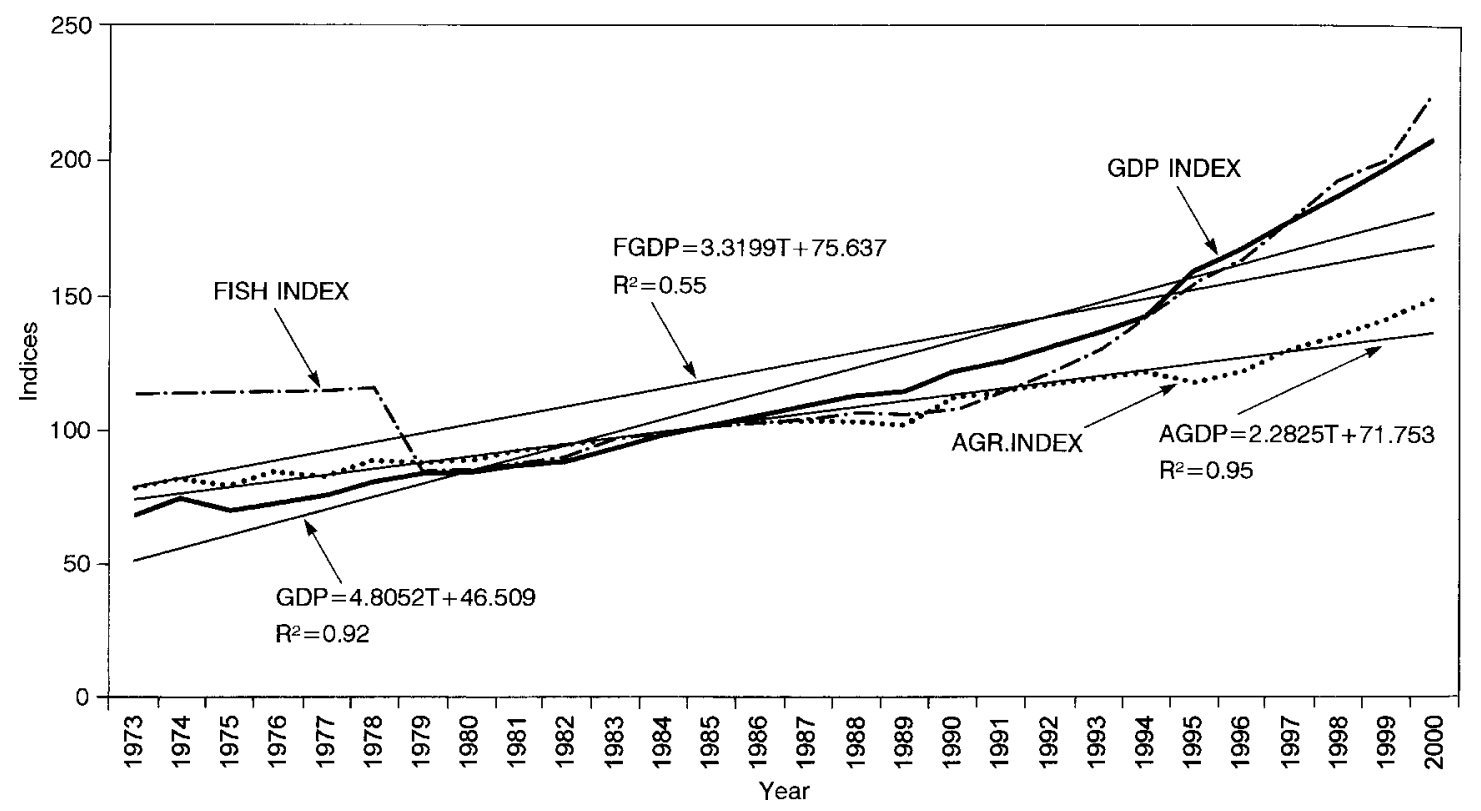

Figure 1. Trends in fisheries and agriculture and total GDP indices.

Table 1. Allocation and utilization of funds in the successive plan periods (million US\$ at base year prices).

\begin{tabular}{|c|c|c|c|c|c|c|c|}
\hline Plan period & $\begin{array}{c}1^{\text {st }} \text { FYP } \\
(1973-78)\end{array}$ & $\begin{array}{l}\text { 2-Year Plan } \\
\qquad(1978-80)\end{array}$ & $\begin{array}{c}2^{\text {nd }} F Y P \\
(1980-85)\end{array}$ & $\begin{array}{c}3^{\text {rd }} \text { FYP } \\
(1985-90)\end{array}$ & $\begin{array}{c}4^{\text {th }} \text { FYP } \\
(1990-95)\end{array}$ & $\begin{array}{c}\text { 2-Year Plan } \\
\text { Holiday } \\
(1995-97)\end{array}$ & $\begin{array}{c}5^{\text {th }} \text { FYP } \\
(1997-02)\end{array}$ \\
\hline \multicolumn{8}{|l|}{ Plan allocation of funds } \\
\hline Total planned budget (public sector), US\$ million & 4,977 & 2,165 & 13,607 & 8,938 & 11,248 & 5,214 & 18,894 \\
\hline Agricultural allocation, ${ }^{\mathrm{a}}$ US $\$$ million & 1,311 & 596 & 4,395 & 2,524 & 2,530 & na & 2,844 \\
\hline Fisheries sector allocation, US\$ million & 61.1 & 29.2 & 117.8 & 125.1 & 136.1 & na & 128.9 \\
\hline Share of fisheries in agricultural sector, $\%$ & 4.66 & 4.90 & 2.68 & 4.96 & 5.38 & na & 4.53 \\
\hline Share of fisheries in total plan allocation, $\%$ & 1.23 & 1.35 & 0.87 & 1.40 & 1.21 & na & 0.68 \\
\hline \multicolumn{8}{|l|}{ Utilization of funds } \\
\hline Revised allocation in fisheries, ${ }^{\mathrm{b}}$ US\$ million & 46.6 & 32.0 & 123.6 & 93.7 & na & na & na \\
\hline Utilization of planned allocation to fisheries, $\%$ & 39.2 & 87.7 & 90.8 & 32.5 & na & na & na \\
\hline Utilization of actual allocation to fisheries, $\%$ & 51.4 & 80.1 & 86.6 & 43.4 & na & na & na \\
\hline \multicolumn{8}{|l|}{ Official exchange rate } \\
\hline Taka/US\$ & 7.94 & 15.06 & 14.79 & 27.97 & 30.85 & 41.65 & 45.46 \\
\hline Base year & 1973-74 & $1978-79$ & 1980-81 & $1985-86$ & 1990-91 & 1995-96 & 1997-98 \\
\hline
\end{tabular}

Notes:

a Agricultural sector includes rural development and institutions sector.

${ }^{b}$ Revised allocation refers to actual allocation in Annual Development Programs (ADP) and/or Revised Annual Development

Programs (RADP).

Sources: PC (1998, 1995b, 1990, 1985, 1983, 1978 and 1973), BBS (2001b), BB (1996), and Bhuiyan and Rahman (1991).

accelerated from the fourth plan phase (Table 3), again making a strong case for prioritizing this sector as a potential foreign exchange earner. The fall in the share of export earnings may be due to changes in the composition of export earnings from agriculture and allied products to industrial products, particularly garments.

Yield estimates for fish from inland waters classified under major categories of capture and culture fisheries ${ }^{2}$ for selected years covering the period from 1984 to $1998^{3}$ reveal the diverging yield gap between capture and culture fisheries (Figure 4). Yields from culture fisheries in
1984 were five times higher than from capture fisheries, estimated at 573 and $117 \mathrm{~kg} / \mathrm{ha} /$ year respectively. By 1998, the gap had increased 13-fold, as the yield of culture fisheries jumped to $1,950 \mathrm{~kg} / \mathrm{ha} /$ year (compare capture fisheries at only $153 \mathrm{~kg} / \mathrm{ha} /$ year), indicating that culture fisheries, particularly pond aquaculture, hold tremendous potential to increase fish production (estimated fish yield in ponds was $2,832 \mathrm{~kg} / \mathrm{ha} /$ year in 1998). The estimates of growth rate in fish yields from all major sources of inland waters (presented in the lower section of Table 3) also confirm the higher potential of culture fisheries. 


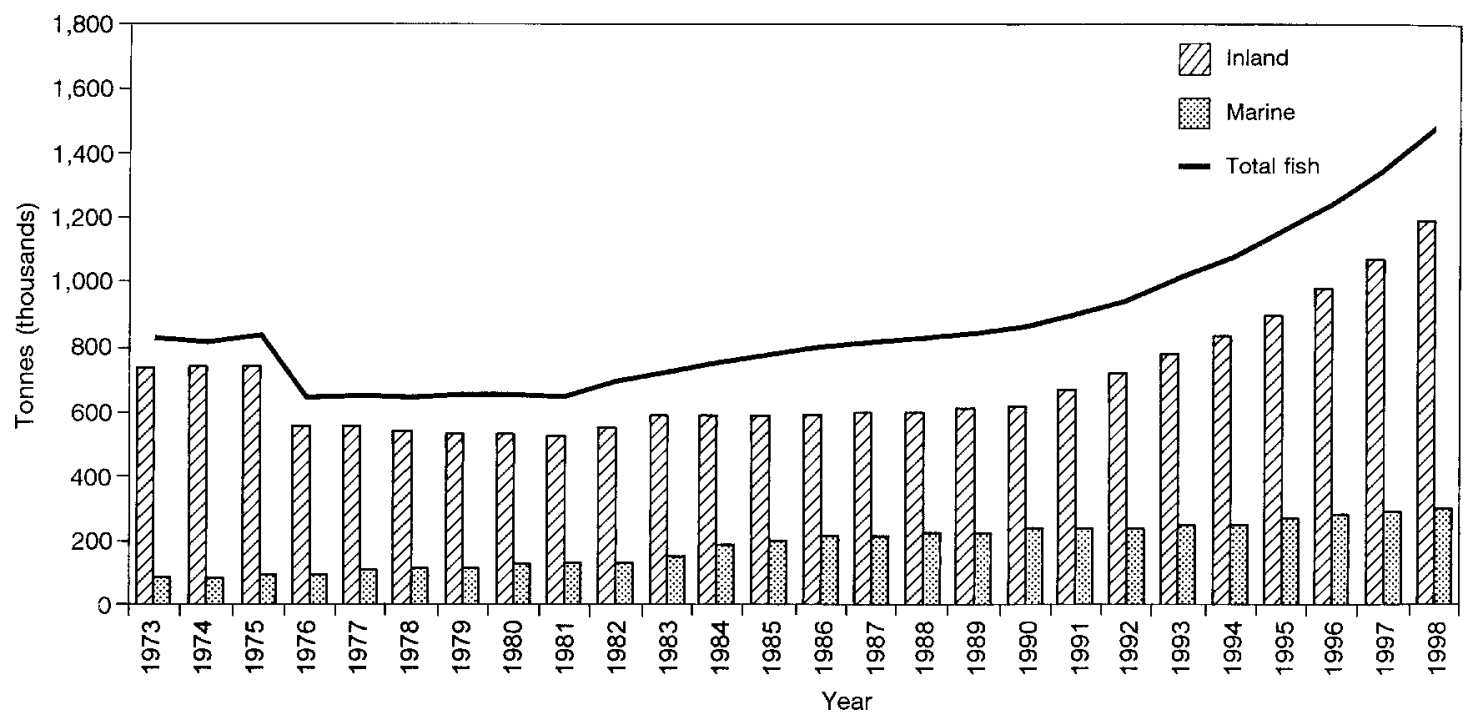

Figure 2. Trends in inland and marine fish production.

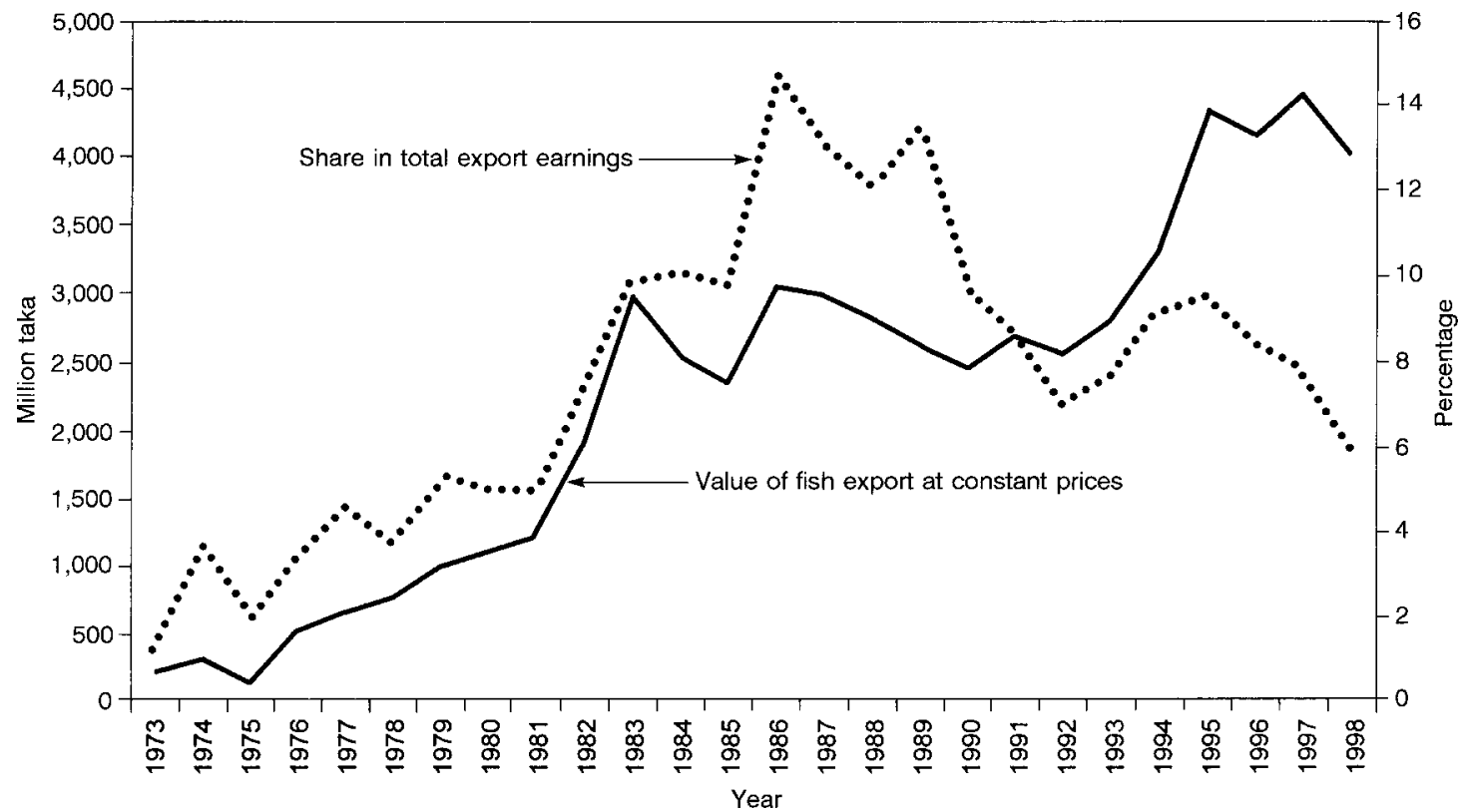

Figure 3. Trends in fish and fish product export and its share in total export earnings.

Table 2. Targets and achievements of fish production from different fishery sources in the terminal year of successive plan periods.

\begin{tabular}{|c|c|c|c|c|c|c|}
\hline \multirow[t]{2}{*}{ Fishery source } & \multicolumn{2}{|c|}{ Second Five-Year Plan } & \multicolumn{2}{|c|}{ Third Five-Year Plan } & \multicolumn{2}{|c|}{ Fourth Five-Year Plan } \\
\hline & Target & Achievement & $\begin{array}{c}\text { Target } \\
\text { (in thousa }\end{array}$ & $\begin{array}{l}\text { Achievement } \\
\text { tric tonnes) }\end{array}$ & Target & Achievement \\
\hline Floodplains & 249.8 & $194.1(78)$ & 213.4 & $178.0(83)$ & 237.5 & $330.0(139)$ \\
\hline Ponds & 126.1 & $111.6(88)$ & 195.1 & $161.0(82)$ & 308.9 & $274.5(89)$ \\
\hline Coastal aquaculture & 105.0 & $11.3(11)$ & 34.7 & $27.0(78)$ & 81.0 & $47.0(58)$ \\
\hline Rivers and estuaries & 217.0 & $219.8(101)$ & 254.4 & $190.0(75)$ & 210.0 & $193.0(92)$ \\
\hline Beels and baors & 123.0 & $46.9(38)$ & 79.0 & $51.6(65)$ & 73.1 & $56.5(77)$ \\
\hline Kaptai Lake & 9.2 & $2.7(29)$ & 8.1 & $5.0(62)$ & 7.5 & $5.0(67)$ \\
\hline Total inland fisheries & 833.3 & $586.4(70)$ & 784.7 & $612.6(78)$ & 938.0 & $906.0(97)$ \\
\hline Marine fisheries & 182.9 & $187.5(102)$ & 231.6 & $234.5(101)$ & 262.0 & $264.0(101)$ \\
\hline All fisheries & $1,016.2$ & $773.9(76)$ & $1,016.3$ & $847.1(83)$ & 1,200 & $1,170.0(97)$ \\
\hline
\end{tabular}

Note: Figures in parentheses are percentages of targets achieved.

The terminal years are 1984/85 for the Second Five-Year Plan, 1989/90 for the Third Five-Year Plan, and 1994/95 for the Fourth Five-Year Plan respectively.

Figures may not add up to total due to omission of fish catch in irrigation canals and ditches.

Sources: PC (1998, 1995b, 1985 and 1983) and DoF (1993, 1990 and 1985). 
Table 3. Growth in production, export and yield level of fish and fisheries products.

\begin{tabular}{|c|c|c|c|c|}
\hline \multirow{3}{*}{$\begin{array}{l}\text { Variables } \\
\text { Plan period } \\
\text { Year }\end{array}$} & \multicolumn{4}{|c|}{ Growth rates (\%) } \\
\hline & $1^{\text {st }}$ to $5^{\text {th }}$ plan & $2^{\text {nd }}$ to $5^{\text {th }}$ plan & $3^{\text {rd }}$ to $5^{\text {th }}$ plan & $4^{\text {th }}$ to $5^{\text {th }}$ plan \\
\hline & $1973-98$ & $1981-98$ & $1986-98$ & $1991-98$ \\
\hline \multicolumn{5}{|l|}{ Production growth } \\
\hline Inland waters & 1.99 & 4.29 & 6.13 & 8.47 \\
\hline Marine waters & 5.51 & 4.78 & 2.83 & 3.37 \\
\hline Total fish production & 2.63 & 4.39 & 5.33 & 7.27 \\
\hline \multicolumn{5}{|l|}{ Export growth } \\
\hline Quantity of export & - & 7.86 & 4.97 & 6.65 \\
\hline Value of export (current prices) & 23.10 & 16.01 & 12.81 & 16.89 \\
\hline Value of export (constant prices) & 11.31 & 4.54 & 3.96 & 8.45 \\
\hline \multicolumn{5}{|l|}{ Yield growth } \\
\hline Inland capture fisheries & - & - & 3.63 & 4.57 \\
\hline Rivers and estuaries & - & - & -2.13 & 3.72 \\
\hline Floodlands & - & - & 7.79 & 5.36 \\
\hline Beels & - & - & 4.01 & 5.67 \\
\hline Kaptai Lake & - & - & 8.50 & 10.92 \\
\hline Inland culture fisheries & - & - & 8.51 & 12.49 \\
\hline Ponds & - & - & 9.37 & 12.24 \\
\hline Baors & - & - & 10.82 & 13.33 \\
\hline Shrimp farms & - & - & 10.33 & 19.93 \\
\hline All inland waters & - & - & 6.03 & 8.35 \\
\hline
\end{tabular}

Note: Columns report the growth rates from year 1 of the implementation of successive five-year plans to the terminal year under consideration, ie year 1 of the implementation of $5^{\text {th }}$ plan.

Sources: Computed from BBS (2001b, 1998, 1996, 1990, 1987 and 1980), DoF (1998, 1993, 1990 and 1985), and BB (1996).

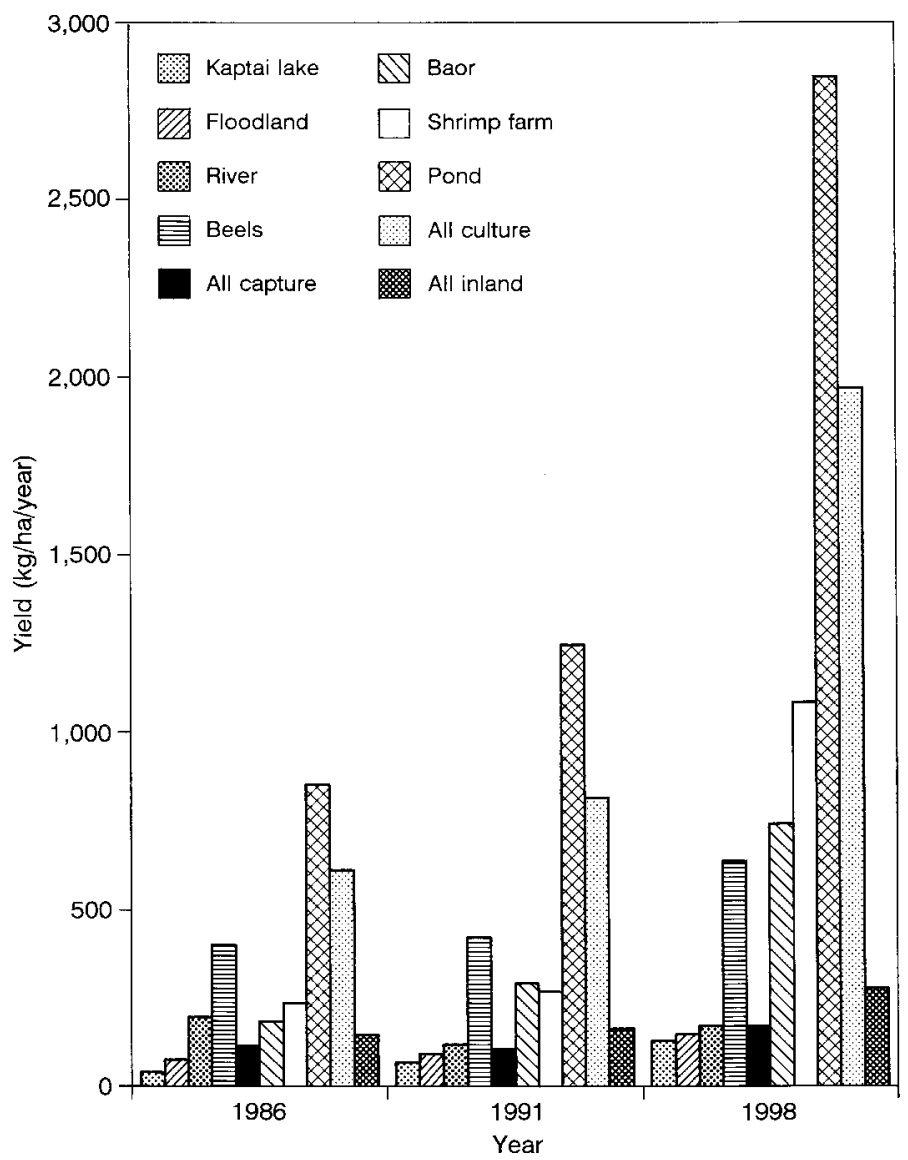

Figure 4. Trends in yield levels of fish (kg/ha/year) from capture fisheries (including Kaptai Lake, flooodlands, rivers, estuaries and beels), culture fisheries (including baors, shrimp farms and ponds) and all inland sources (selected years).

\section{Target set in the Fifth Five-Year Plan}

Although fish production has increased sharply in recent years, it still seems to be incompatible with the ambitious target set in the Fifth Five-Year Plan (1997-2002). This plan envisaged an increase in per capita daily consumption from its existing level of $25.6 \mathrm{gm}$ in 1996/97 to $34.4 \mathrm{gm}$ by the year 2002 (PC, 1998). In addition, assuming that an estimated 95,000 tons of shrimp, fish and fish products are expected to be exported in 2001/02 and 15,000 tons of fish to be required for industrial and other uses, the production target for the terminal year of the plan is now set at $2.08 \mathrm{~m} \mathrm{t}(\mathrm{PC}, 1998)$. This target implies that in five years (by the end of 2002) fish production should have increased by $51 \%$ from its base of $1.17 \mathrm{~m} \mathrm{t}$ in $1996 / 97$, or by roughly $10 \%$ per year. Given the growth rate performance in Table 3, it is highly unlikely that this target can be reached. For instance, the realized fish production in mid-1998 was $1.49 \mathrm{~m} \mathrm{t}$ (BBS, 2001b), indicating that production increased by only $8 \%$ from its base in the first 1.5 years of the plan's horizon. Therefore, if the planned target is to be achieved, production must have increased by $13 \%$ per year during the last 3.5 years of the plan's horizon. Our latest estimate shows that fish production grew at an annual rate of only $7.3 \%$ during the 1991-98 period (last column of Table 3), thereby reinforcing the conclusion that the target is very likely to be missed by a considerable margin.

\section{Current constraints in the fisheries sector}

A host of interrelated factors, technical, institutional and social, constrain the development of the fisheries sector in Bangladesh. Fluctuations in inland fisheries production have been attributed to: 
(1) overfishing owing to population pressure;

(2) indiscriminate killing of undersized and juvenile fish;

(3) destruction of spawning grounds;

(4) breakdown of natural routes of fish migration due to unplanned construction of Flood Control Drainage and Irrigation (FCD/I) projects;

(5) shrinking of floodplain areas to provide for irrigated rice monoculture;

(6) siltation of major rivers and their tributaries due to large-scale sediment flows from the upper watershed of neighbouring countries through its major river channels, finally discharging them into the Bay of Bengal; and

(7) a reduction in the availability of wild fish in open water bodies due to increased use of agrochemicals, eg fertilizers and pesticides (Lewis, 1997; PC, 1998; Alam and Thomson, 2001).

On the other hand, the marine fisheries suffer from:

(1) lack of proper capital, equipment and technological know-how to exploit the resources within the EEZ;

(2) congestion caused by low-technology-based artisanal fishermen near the shoreline, leading to meagre catches;

(3) inadequate information on existing stock; and

(4) inadequate harbour and landing facilities (Lewis, 1997; PC, 1998; and Alam and Thomson, 2001).

However, performance reviews of successive plans undertaken by the government largely focused on the biophysical and technical constraints while, to a large extent, bypassing the institutional and social constraints. The consequence was a repetition of similar strategies in addressing the partially identified issues, resulting in the usual ineffective and undesired outcomes. This is a common occurrence with substantial initiatives undertaken by the government, which frequently end up as costly experiments with little or no tangible outcomes.

The main focus of the government remained on raising the productivity of inland open waters. The prominent initiatives included:

(1) the New Fisheries Management Policy (NFMP), launched in 1987 to ensure access of genuine fishermen to open water fisheries (known as jalmahals) and to protect fishermen from exploitation by middlemen;

(2) stocking programmes in floodplains and open water including rivers; and

(3) some initiatives involving NGOs in fisheries development via organization of the poor within a community-based fisheries management framework.

Although NFMP revealed some benefit on incomes distribution from the exploitation of open water fisheries, the continuation of such activities often requires additional inputs of resources, as with the World Bankfinanced Fourth Fisheries Project costing around Tk3,000 million - US\$53 million (Alam and Thomson, 2001).

Stocking programmes in the floodplains and open water bodies including rivers, which are also highly expensive, failed to show beneficial results because of indiscriminate catching of undersized, juvenile and brood fish. It is worth mentioning that stocking policy as a management option adopted in the Kaptai reservoir did not prove to be very successful, either through taking fish before a harvestable size was attained, or through the indiscriminate use of fishing gear of small and unregulated mesh size (Ahmed et al, 2001).

The Ministry of Fisheries and Livestock (MoFL), Department of Fisheries (DoF), Bangladesh Fisheries Development Corporation (BFDC) and the Bangladesh Fisheries Research Institute (BFRI) demonstrate serious problems of coordination and overlapping responsibilities, which delay the implementation of development projects (Bhuiyan and Rahman, 1991). Institutional linkage between DoF and BFRI is also very weak, resulting in poor extension-research linkages.

There are also marketing bottlenecks coupled with poor production performance in the fisheries sector. The BFDC has been de-prioritized since the last phase of the Third Five-Year Plan due to its continuing financial losses. Only a small proportion of fish (about $2 \%$ ) is marketed by BFDC, which is completely insufficient to stabilize the fish market (Bhuiyan and Rahman, 1991). Fish trading remains concentrated in the hands of a limited number of middlemen at various locations where they control storage facilities, fish landing and the pricing structure, thereby removing any large marketing margins from within the trading chain.

Also, in recent years urban markets have been flooded with imported carp (eg Ruhi, Catla and Mrigala) from neighbouring countries. The foreign trade statistics show that imports of fish and fish products, which did not exist until 1993/94, started at Tk0.2 million in 1994/95 (US\$3,500), jumped to Tk31.5 million (US\$557,500) in $1997 / 98$ and fell to Tk1.6 million (US\$28,300) in 1998/99 at current prices (BBS, 2001b). The erratic fish supply in the urban market induces traders to import fish, mainly carp, to fulfil the demand. The inducement appears to arise from an income-inelastic demand for carp by the rich urban consumers who consider it as a necessity whilst the poor treat it as a luxury item.

The focus of fisheries research has been confined to raising fish production. For example, the UK Department for International Development (DFID)-funded NorthWestern Fisheries Project, launched in 1988 at a cost of $\$ 2.8$ million, was primarily a production-oriented project aimed at developing a major hatchery. However, during the second phase in recent years, the focus has shifted to research and extension working with both local NGOs and the government (Lewis, 1997). Even in the fifth plan, the high priority research topics included the commissioning of a study to identify the cause and sources of disease in fish and shrimps, since a viral epidemic was destroying substantial quantities of both capture and culture fish.

The extension service also lacks any overall strategy for developing aquaculture activities and has a tendency to respond to externally imposed projects. DoF was solely endowed with the responsibility of fisheries extension but, like many other government organizations, its activity is hampered by a severe lack of resources and trained personnel and it is plagued with rigid bureaucracies.

\section{Future possibilities and policy implications}

A large part of the failure of past plans to achieve fish production targets was most likely due to inconsistent 
approaches in prioritizing needs, and to the failure to set realistic targets and make institutional reforms.

Experience shows that the planning approach undertaken by the government has largely been production-oriented, focusing on raising the production levels of fish from inland water bodies, and to some extent from marine waters. Also, in all past plans, including the fifth plan, a comprehensive set of laws and regulations for protecting and facilitating the development of the fisheries sector, particularly capture fisheries, may have been mentioned but their effective enforcement has remained poor and no implementation strategy or provision of support services was outlined. The performance analysis considered above clearly reveals that there is huge potential in this sector so long as the bottlenecks are released. This section highlights the few points that deserve consideration to improve the performance of the fisheries sector.

\section{Social versus technical issues}

Thus far, both the public and private sectors have emphasized a technical approach to fisheries development while ignoring the socioeconomic and distributional aspect of these programmes. For example, semi-intensive shrimp farming, practised in the coastal belts, although aided substantially by raised export earnings, has entangled itself with serious negative environmental consequences and highly skewed economic benefits in favour of the rich (Lewis, 1997). The action of NGOs in promoting aquaculture through group organizations helped to raise fish production and incomes of the poor to some extent, but the outcomes were not always attractive (Worby and Karim, 1994, cited in Lewis, 1997).

There is a realization that the constraints to increasing production, consumption and incomes of the poor are largely social (unequal access to inputs and resources) rather than technical (Worby, 1994, cited in Lewis, 1997). Insecurity of tenure, access to open water bodies, and multiple pond ownership are currently major impediments to aquaculture development. These need to be addressed by setting up clear policy guidelines and by the effective involvement of NGOs and others.

\section{Large-scale versus small-scale fisheries}

It is now recognized that the promotion of small-scale fisheries, rather than large-scale commercial ones, provides most of the fish consumed by people in the developing nations. It requires less capital, produces more employment opportunities per unit of capital, yields fewer skewed benefits and has more potential to provide nutritional benefits (Kent, 1997). Therefore, it would be advisable for the government to consider changing its stand from undertaking a handful of large-scale, commercially oriented projects for fisheries development to a large number of small-scale fisheries development programmes, such as pond aquaculture.

\section{Prospects of pond aquaculture}

A large number of ponds in the country are either not used for aquaculture or are derelict, and only $52.2 \%$ out of $0.21 \mathrm{~m}$ ha of pond area are currently under pond aquaculture (BBS, 2001a), implying that huge but unexploited potential exists. The yield level in ponds and the accelerating growth rate (Figure 4 and Table 3 ) show reassuring potential once the institutional issues, such as joint ownership of ponds, input and service deliveries and marketing infrastructure are addressed. Productivity in existing ponds used for aquaculture can be raised dramatically by improving efficiency without resorting to additional resources. The current level of technical efficiency of pond carp aquaculture under the extensive farming system is only $48 \%$ (Sharma and Leung, 2000), implying that huge potential exists for raising productivity. The promotion of pond aquaculture could be a priority policy, as it promises increased production without requiring additional resources.

\section{Prospects of shrimp farming}

Shrimp farming in coastal waters in Bangladesh is predominantly extensive, with only $10 \%$ of production obtained from semi-intensive farms. But both operate at a very poor level of efficiency, in the order of only $11 \%$ and $48 \%$ of those of their most efficient peers within the Asian region (Shang et al, 1998). Furthermore, given the same level of input prices, shrimp farming in Bangladesh costs approximately $12 \%$ more than in the Philippines, thereby indicating limited potential for any comparative advantage to boost export earnings (Ling et al, 1999). In fact, Bangladesh has a comparative advantage only under extensive shrimp farming systems, but even those have low productivity rates, estimated at $216 \mathrm{~kg} / \mathrm{ha} / \mathrm{year}$, and make a net loss under the semi-intensive farming system (Shang et al, 1998; and Ling et al, 1999). Therefore, considering the current level of poor efficiency coupled with the negative environmental consequences that this particular subsector has already caused, the options also need to be rethought in the light of the trade-offs involved in developing this sector to boost export earnings, as there are adverse income distributional consequences as well.

\section{Stocking as a management option to support subsistence fishermen}

An estimated 13.3 million households are engaged in fishing in the floodlands, with an average annual catch, as revealed from the Catch Assessment Survey of Subsistence Fisheries by DoF in 1998, of $28.4 \mathrm{~kg}$ of fish per household (BBS, 2001a). However, it must be reemphasized that past experience of stocking programmes failed to show satisfactory results due to poor enforcement of catch regulations. Therefore, a clearly defined implementation and law enforcement strategy must be in place to achieve success from this management option, which has the potential to benefit the large masses of poor subsistence fishermen and also to justify the large expenses required to finance such efforts.

\section{Prospects of marine fisheries}

Despite the existence of huge bottlenecks, promises from marine fisheries deserve due consideration. Past experience clearly showed that, despite less attention being paid to this sector, the growth in marine fish production continued at a slow pace. Although there is a lack of domestic demand for marine fish for consumption, the export potential for fish for consumption and/or industrial usage is high, provided that competitiveness in the world market can be achieved. Improvement in the fisheries infrastructure and processing industries, the 
provision of up-to-date information on the nature and type of stocks available ${ }^{5}$ and the promotion of low-cost adaptive fishing gear and craft can boost the performance of this subsector.

\section{Research focus}

The research efforts of BFRI have provided some valuable returns, such as guidelines on stocking combinations for each agroecological zone of Bangladesh, adaptive research on the development of poultry-fish farming technology, integrated rice-fish farming, and the production of Silver Barb, etc (Lewis, 1997). However, this institute needs to be strengthened to promote inter-institutional research through a clearly defined set of policy guidelines that recognize the synergy between social and equity issues and research programmes for developing aquaculture technology and its delivery. In other words, emphasis is needed for field-oriented and applied research programmes and for developing strategies to improve links with extension agencies and with NGOs involved in the development of fisheries.

\section{Fisheries extension}

The adoption and spread of fishing technologies depend mainly on the quality and effectiveness of extension services once the research results are suitable for dissemination. Under the current fisheries extension service system, extension personnel are charged with the dual responsibility of promoting improved fishery technologies and identifying and handling defaulters of fisheries regulations. It is questionable as to how far these combined roles prejudice both the extension role of the fishery officers with the intended technology adopters and the effective enforcement of fisheries regulations. There must be a reorientation or creation of a separate cell to enforce fisheries regulations. In addition, the field level officials (eg Thana fisheries officers) currently responsible for enforcing fisheries laws, lack proper training, field experience and vessels needed to monitor large bodies of water. However, successive plans have not focused on the urgency of such support services or outlined any strategies to address these problems other than to mention their importance.

\section{Fisheries infrastructure and linkages}

The fisheries infrastructure, particularly the storage and marketing infrastructure, needs to be developed in order to ensure that the catch of the large number of subsistence fishermen is properly marketed and their due share received. It is believed that approximately $30-33 \%$ of all fish caught becomes spoiled and unsuitable for human consumption (PC, 1998).

One major impediment to the promotion of the fisheries sector in Bangladesh is its poor inter-sector linkages. The feed market in Bangladesh has not been developed and is largely import-based. For example, seed and feed costs for semi-intensive shrimp farming are estimated at $22.4 \%$ and $26.3 \%$ of total cost respectively. The seed cost alone is estimated at $43.5 \%$ in extensive systems (Shang, et al, 1998). All this rules out Bangladesh as a serious player in semi-intensive shrimp farming. Also, the quality of processing industries is highly variable and mainly poor. For example, improvements to the infrastructure and hygiene in the processing industries following a ban on seafood exports to the EU nations in 1997 cost the government an estimated \$15 million for shrimp exports alone (Alam and Thomson, 2001). Emphasis should, therefore, be placed on improving the state of fisheries infrastructure to reduce wastage if Bangladesh is to gain competitiveness in world export markets.

\section{Building partnerships}

If the fisheries sector is to meet its tripartite role of supplying protein, generating employment and earning foreign exchange for the economy, then the complex interdependencies involving various stakeholders need to be understood and clearly spelled out in any development plans. A firm commitment to building partnerships across agencies, both governmental and private, is vital, as most of the problems faced in the fisheries sector require institutional solutions. For instance, the construction of FCD/I projects in the 1980s and 1990s were largely responsible for destroying the conventional fish paths and breeding grounds in open water bodies (Ali, 1989; and World Resources Institute (WRI), 1990). Also, the intensification of field crop agriculture for achieving selfsufficiency has been accompanied by increased use of chemicals (eg inorganic fertilizers and pesticides), which have also exerted some detrimental effects on fisheries in the floodplains (Rahman and Thapa, 1999).

\section{Conclusions}

It is apparent that the government needs to widen its approach to planning for the fisheries sector by seeking solutions to social and institutional issues in addition to focusing on technical issues. Above all, the top-down bureaucratic view currently employed by the government in planning, implementing and managing the fisheries sector needs to be restrained and a more participatory bottom-up approach introduced that recognizes the vital role of interagency partnership and builds upon its strengths.

\section{Acknowledgments}

An earlier version of this paper was presented at the Fifth Asian Fisheries Forum on Fisheries and Food Security Beyond the Year 2000, held at the Lotus Hotel, Pang Suan Kaew, Chiang Mai, Thailand from 11-14 November 1998.

\section{Notes}

${ }^{1}$ The preparation of this 15 -year plan may have led to a delay of two years in setting the Fifth Five-Year Plan (1997-2002), giving rise to a two-year plan holiday for the period 1995-97.

${ }^{2}$ Capture fisheries include rivers and estuaries, floodlands, beels and the Kaptai Lake. Culture fisheries include ponds, baors and shrimp farms.

${ }^{3}$ The yield statistics are available only from the year 1983/84 onwards (collected by the Department of Fisheries).

${ }^{4}$ Dey (2000) reported fish expenditure elasticity of 1.52 for the poorest quartile households and 0.62 for the richest quartile, suggesting that the income elasticity of demand for fish falls with an increase in income. This implies that fish is a luxury commodity for the poor and a necessity for the rich.

${ }^{5}$ Marine fishing surveys, which formed the basis of much of the planning, were carried out in the 1960s and 1970s and are now appreciably outdated (Alam and Thomson, 2001). 


\section{References}

Ahmed, K. K., Hambrey, J. B., and Rahman, S. (2001), 'Trends in interannual yield variation of reservoir fisheries in Bangladesh, with special reference to Indian major carps', Lakes and Reservoirs: Research and Management, Vol 6, pp 85-94.

Alam, M. F., and Thomson, K. J. (2001), 'Current constraints and future possibilities for Bangladesh fisheries', Food Policy, Vol 26, pp 297-313.

Ali, M. (1989), 'Environment, conservation and fishery resources in Bangladesh', in M. Aguero, S. Huq, A. K. A. Rahman, and M. Ahmed, eds, Inland Fisheries Management in Bangladesh, International Centre for Living Aquatic Resources Management (ICLARM), Manila.

BB - Bangladesh Bank (1996), Economic Trends, Vol 22, No 12, Statistics Department, Bangladesh Bank, Dhaka.

BBS - Bangladesh Bureau of Statistics (1980), Statistical Yearbook of Bangladesh, 1980, Bangladesh Bureau of Statistics, Dhaka.

BBS (1987), Statistical Yearbook of Bangladesh, 1987, Bangladesh Bureau of Statistics, Dhaka.

BBS (1990), Statistical Yearbook of Bangladesh, 1990, Bangladesh Bureau of Statistics, Dhaka.

BBS (1996), Statistical Yearbook of Bangladesh, 1995, Bangladesh Bureau of Statistics, Dhaka.

BBS (1998), Statistical Yearbook of Bangladesh, 1997, Bangladesh Bureau of Statistics, Dhaka.

BBS (2001a), Yearbook of Agricultural Statistics of Bangladesh, 1999, Bangladesh Bureau of Statistics, Dhaka.

BBS (2001b), Statistical Yearbook of Bangladesh, 1999, Bangladesh Bureau of Statistics, Dhaka.

Bhuiyan, S. R., and Rahman, S. (1991), 'Fisheries planning performance and Fourth Five-Year Plan', Farm Economy, Vol 8, pp 109-121.

Dey, M. M. (2000), 'Analysis of demand for fish in Bangladesh', Aquaculture Economics and Management, Vol 4, pp 65-83.

DoF - Department of Fisheries (1986), Fish Catch Statistics of Bangladesh, 1985/86, Department of Fisheries, Government of Bangladesh, Dhaka.

DoF (1990), Fish Catch Statistics of Bangladesh, 1989/90, Department of Fisheries, Government of Bangladesh, Dhaka.

DoF (1993), Fish Catch Statistics of Bangladesh, 1992/93, Department of Fisheries, Government of Bangladesh, Dhaka.

DoF (1998), Fish Catch Statistics of Bangladesh, 1997/98, Department of Fisheries, Government of Bangladesh, Dhaka.

Kent, G. (1997), 'Fisheries, food security, and the poor', Food
Policy, Vol 22, pp 393-404.

Lewis, D. (1997), 'Rethinking aquaculture for resource-poor farmers: perspectives from Bangladesh', Food Policy, Vol 22, pp 533-546.

Ling, B-H., Leung, P. S., and Shang, Y. C. (1999), 'Comparing Asian shrimp farming: the domestic resource cost approach', Aquaculture, Vol 175, pp 31-48.

MPO - Master Plan Organization (1989), Fisheries and Flood Control, Drainage and Irrigation Development, Technical Report No 17, Master Plan Organization, Bangladesh, Dhaka.

PC - Planing Commission (1973), The First Five-Year Plan (19731978), Ministry of Planning, Government of Bangladesh, Dhaka.

PC (1978), The Two-Year Plan (1978-1980), Ministry of Planning, Government of Bangladesh, Dhaka.

PC (1980), The Second Five-Year Plan (1980-1985), Ministry of Planning, Government of Bangladesh, Dhaka.

PC (1985), The Third Five-Year Plan (1985-1990), Ministry of Planning, Government of Bangladesh, Dhaka.

PC (1990), The Fourth Five-Year Plan (1990-1995), Revised Draft, Ministry of Planning, Government of Bangladesh, Dhaka.

PC (1995a), Participatory Perspective Plan for Bangladesh (19952010), Final Draft, Ministry of Planning, Government of Bangladesh, Dhaka.

PC (1995b), The Fourth Five-Year Plan (1990-1995), Revised Draft, Ministry of Planning, Government of Bangladesh, Dhaka.

PC (1998), The Fifth Five Year Plan (1997-2002), Ministry of Planning, Government of Bangladesh, Dhaka.

Rahman, S., and Thapa, G. B. (1999), 'Environmental impacts of technological change in Bangladesh agriculture: farmers' perceptions and empirical evidence', Outlook on Agriculture, Vol 28, No 4, pp 233-238.

Shang, Y. C., Leung, P. S., and Ling, B-H. (1998), 'Comparative economics of shrimp farming in Asia', Aquaculture, Vol 164, pp 183-200.

Sharma, K. R., and Leung, P. S. (2000), 'Efficiency of carp pond culture in South Asia: an application of a stochastic metaproduction frontier model', Aquaculture Economics and Management, Vol 4, pp 169-190.

TFR - Task Force Report (1991), Managing the Development Process: Bangladesh Development Strategies, Volume 2, University Press Limited, Dhaka.

WRI - World Resources Institute (1990), Bangladesh: Environment and Natural Resource Management, World Resources Institute, Washington, DC. 